\title{
Community structure of invasive aquatic invertebrates in coral reef ecosystems in the KKPD PISISI Simeulue
}

\author{
Chitra Octavina ${ }^{1,2,3^{*}}$, Maria Ulfah $^{1,2,3}$, Sri Agustina ${ }^{1,2,3}$, Yayang Rifka Putri ${ }^{1,4}$, Indra Indra $^{5}$ \\ ${ }^{1}$ Departement of Marine Sciences, Faculty of Marine and Fisheries, Universitas Syiah Kuala, Indonesia \\ ${ }^{2}$ Research Center for Marine and Fisheries, Universitas Syiah Kuala, Indonesia \\ ${ }^{3}$ Laboratory of Marine Biology, Faculty of Marine and Fisheries, Universitas Syiah Kuala, Indonesia \\ ${ }^{4}$ Fauna \& Flora Internasional - Aceh Programme, Aceh, Indonesia \\ ${ }^{5}$ Ocean Diving Club, Faculty of Marine and Fisheries, Universitas Syiah Kuala, Indonesia
}

\begin{abstract}
This study aimed to determine the structure of invasive aquatic invertebrates through the approach, diversity, similarity, dominance, distribution, and comparison of invasive aquatic invertebrates with coral cover in coral reef ecosystems in PISISI KKPD. This research was conducted in September 2019 using the purposive sampling method to research points, collecting invasive aquatic data used the belt transect method and collecting coral reef data used the Point Intercept Transect (PIT) method. The results of the study found that the structure of invasive aquatic invertebrates in KKPD PISISI was in the good category indicated by the density invasive aquatic invertebrates of 39.67 individuals $/ \mathrm{m}^{2}$, the biodiversity index was 1.50 with the medium category, the similarity index is 1.06 in the high category and the dominance index is 0.44 in the low category. The distribution of invasive aquatic invertebrates in the PISISI KKPD includes a cluster distribution. The highest value of invasive invertebrate water was $12.83 \mathrm{ind} / \mathrm{m}^{2}$ and the proportion of coral cover was $29.83 \%$ and the lowest was $3.67 \mathrm{ind} / \mathrm{m}^{2}$ and the proportion of coral cover was $54.67 \%$ showing the effect of invasive aquatic invertebrates on the proportion of coral cover.
\end{abstract}

\section{Introduction}

The Pinang Island, Siumat Island, and Simanaha Island Regional Water Conservation Area (KKPD PISISI) is a marine protected area located in Simeulue Regency which has been established through Aceh Governor Decree Number: 523/1297/2018, which Aan area of 44,404.10 Ha. The PISISI KKPD has enormous marine and fishery potential and is the main source of livelihood for coastal communities living in the PISISI KKPD area. One of the fishing grounds for fish and other marine products is located in the coral reef ecosystem in the PISISIS KKPD.

Coral reefs are a habitat for various marine biota to grow and reproduce [1]. There are biota associated with coral reefs that can cause damage to coral reefs, especially invasive aquatic invertebrates that act as coral predators, thus having an impact on damage to coral community structures or on the abundance of coral species [2]. Invasive species are species that are able to survive in their new environment, reproduce, and spread very widely in their distribution [3]. In addition, according to [4] Invasive species can cause drastic changes to an ecosystem by eradicating native organisms as they compete.

Predation is one of the main ways for invasive species to affect aquatic communities [5]. Coral predators according to [6] cause damage and or loss of coral tissue so that it has a direct impact on the growth of coral colonies and coral survival. Coral predators are a natural part of a healthy coral reef ecosystem, but overcrowding of some predators that are corallivores can result in drastic and widespread reductions in coral cover.

Invasive species studies have been carried out by [7] on invasive marine species that threaten marine biodiversity and industry. A similar study has also been conducted by [3] which discusses the interactions of aquatic invasive species with the natural and anthropogenic environment. Other studies have also been carried out by [8] regarding the distribution of potential invasive tunicates of Didemnum vexillum species. Research on invasive species in Indonesia has been carried out by [9] regarding the distribution of benthic invasion on coral reef ecosystems in the Thousand Islands, Jakarta and by [10] regarding the relationship between coral reef ecosystem conditions and invertebrates that can kill corals in the Thousand Islands, Jakarta.

Aquatic invertebrates act as a balancer in coastal ecosystems including coral reef ecosystems, but if their abundance is high, it can have a negative impact on the sustainability of the coral reef ecosystem. Assessment of invasive aquatic invertebrates on coral reefs still needs to be done, especially in areas that have the potential as conservation areas. Information from this study will be useful in determining the location of conservation area zoning which has a lower level of vulnerability to

\footnotetext{
* Corresponding author: chitraoctavina@unsyiah.ac.id
} 
attacks and threats from invasive aquatic invertebrates. Therefore, researchers feel the need to study invasive aquatic invertebrates, especially in the PISISI KKPD.

\section{Materials and Methods}

\subsection{Site and time}

Data collection was carried out in September 2019 at the KKPD PISISI Simeulue. The research was conducted at seven stations, namely Air Manis Islet, Batee Dua Islet, Putih Islet, Ujung Babang Islet, Gabui Island, Babi Island, and Limau Island (Figure 1).

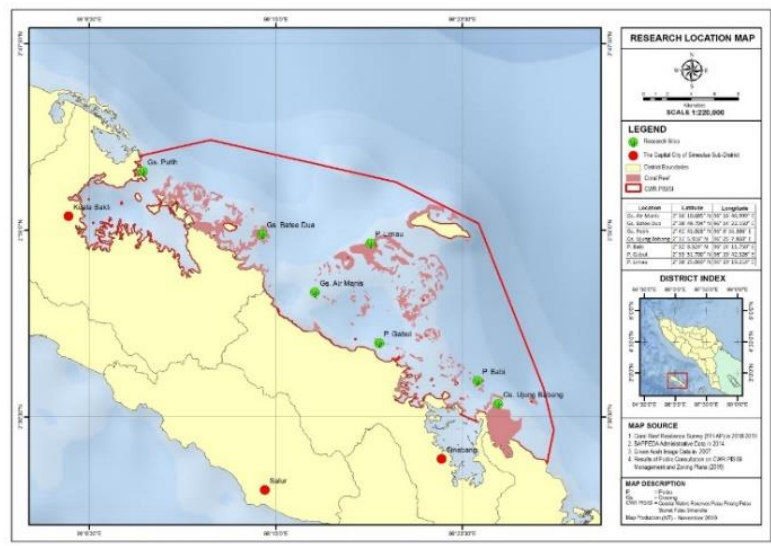

Fig. 1. Map of the research location.

\section{Data Analysis}

\subsection{Station determination}

Determination of the research location using purposive sampling method. The purposive sampling method determines the location chosen based on the sample requirements to suit the research objectives [11]. This research's location was determined based on the representation of the coral reef ecosystem and the affordability of the area for research observations.

\subsection{Invasive aquatic invertebrate data collection}

Invasive aquatic invertebrates were sampled using the belt transect method (Figure 2) by stretching roll meter along $50 \mathrm{~m}$ following the water bed contours with an observation area of $2.5 \mathrm{~m}$ on the left and $2.5 \mathrm{~m}$ on the right. Data were collected at two depths, namely $5 \mathrm{~m}$ and $10 \mathrm{~m}$. Observations were made three times at each station. The recording of invasive aquatic invertebrates was carried out by species and number. Identification of invasive aquatic invertebrate species using the book Tropical Pacific Invertebrates [12].



Fig. 2. Belt transect method.

\subsection{Coral reef data collection}

Coral reef data was collected using the PIT (Point Intercept Transect) method using the same roll meter as the invasive aquatic invertebrates. Data was collected for three replications at each station at a depth of $5 \mathrm{~m}$ and $10 \mathrm{~m}$. Coral reef data was recorded based on the form of growth (lifeform) and coral genus.

\subsection{Water quality data collection}

Aquatic environmental parameter data collection includes chemical and physical parameters at each observation station that has been previously determined. Measurement of the aquatic environment parameters was carried out directly at the research location (in situ) and was carried out three times at each station. According to [13] environmental parameters such as salinity, temperature, $\mathrm{pH}$, and flow velocity can affect the high and low abundance of organisms.

\section{Data analysis}

\subsection{Abundance of invasive aquatic invertebrates}

The Abundance, according to [14], can be calculated using the following formula, namely:

$$
D=\frac{N i}{A}
$$

Where, D is an abundance of species (individuals $/ \mathrm{m}^{2}$ ); $\mathrm{Ni}$ is the total number of individual types (individuals); A is the area sampled $\left(\mathrm{m}^{2}\right)$.

\subsection{Diversity of invasive aquatic invertebrates}

The diversity of invasive aquatic invertebrates can be calculated using the Shannon-Winner formula [14] is:

$$
H^{\prime}=\sum_{i=1}^{s} P i \log 2 P i
$$

Where, $\mathrm{H}^{\prime}$ is diversity Index ( $\left.\mathrm{ind} / \mathrm{m}^{2}\right)$; $\mathrm{Pi}$ is ni/N, number of individuals of species i to total individuals (ind); $\mathrm{N}$ is total number of individuals of all species (ind), $\mathrm{S}$ is number of taxa / species (ind). [14] divides the criteria for diversity with low diversity if the value is less than 1 , moderate diversity if the value is between $1-3$, and high diversity if the value is more than 3 . 


\subsection{Evenness of invasive aquatic invertebrates}

The similarityof invasive aquatic invertebrates can be determined using [14]:

$$
E=\frac{H^{\prime}}{H m a k s}
$$

Where, $\mathrm{E}$ is Evenness Index (ind $\left./ \mathrm{m}^{2}\right)$; $\mathrm{H}^{\prime}$ is diversity index; $\mathrm{H}$ maks is maximum species diversity; $\mathrm{S}$ is number of species found.

The uniformity of invasive aquatic invertebrates can be categorized with an index value of $\mathrm{E}<0.4$ is categorized as low E 0.4-0.6 is categorized as moderate, and $\mathrm{E}>0.6$ is categorized as high [14].

\subsection{Dominance of invasive aquatic invertebrates}

The dominance of invasive aquatic invertebrates can be calculated using the Simpson Dominance Index [14]:

$$
C=\sum\left(\frac{n i}{N}\right)^{2}
$$

Where, $\mathrm{C}$ is dominance index (ind $\left./ \mathrm{m}^{2}\right)$; $\mathrm{ni}$ is number of individuals of the I species (ind); $\mathrm{N}$ is total number of individuals (ind).

According to [14], the dominance criterion is a low category with values ranging from $0.00-0.50$, medium category values ranging from $0.50-0.75$, and high category values ranging from $0.75-1.00$.

\subsection{Distribution of invasive aquatic invertebrates}

The distribution of invasive aquatic invertebrates can be calculated using the Morisita Index [15] with equations:

$$
I d=n \times \frac{\sum X^{2}-N}{N(N-1)}
$$

Where, $I_{d}$ is species distribution index ( $\left.\mathrm{ind} / \mathrm{m}^{2}\right) ; \mathrm{n}$ is Number of plots; $\mathrm{N}$ is total number of individuals acquired (ind); $\Sigma \mathrm{x}^{2}$ is multiplication of the number of species in each plot $(x)$ and the frequency found in the number of plots $\mathrm{f}(\mathrm{x})$. The criteria of Morisita index is Id $=1$, distribution pattern is random; $\mathrm{Id}<1$, is uniform, Id $>1$ is cluster.

\subsection{Percentage of coral reef cover}

The calculation of the percentage of coral reef cover is carried out by comparing each category's total length with the total length of the transect using the following formula [16]:

Percent Cover $=\frac{\text { Number } \text { found }}{\text { Number of dots }} \times 100 \%$

The standard criteria for coral reef damage according to based on [17] the percentage of the area of live coral cover can be categorized as follows: $0-24,9 \%$ is bad;
$25-49,9 \%$ is moderate; $50-74,9 \%$ is good; $75-$ $100 \%$ is very good.

\section{Results and Discussion}

\subsection{Community structure of invasive aquatic invertebrates}

The observations the study found five invasive aquatic invertebrates from 5 different families in the coral reef ecosystem in the KKPD PISISI; namely Acanthaster planci, Culcita novaeguinaea, Diadema antillarum, Drupella sp., and Spirobranchus giganteus. The total abundance value of invasive aquatic invertebrates in the KKPD PISISI was $39.67 \mathrm{ind} / \mathrm{m}^{2}$ (Figure 3 ).

The highest abundance of invasive aquatic invertebrates was found at station Batee Dua Islet, with a total number of $12.83 \mathrm{ind} / \mathrm{m}^{2}$ and the lowest abundance of invasive aquatic invertebrates, was found at the Limau Island station as much as $3.17 \mathrm{ind} / \mathrm{m}^{2}$. This study's results are different from the results of research conducted by [18] in Morowali where the highest abundance value of aquatic invertebrates was 2.37 ind $/ \mathrm{m}^{2}$, and the lowest was $2.13 \mathrm{ind} / \mathrm{m}^{2}$. Other research conducted by [19] in Ambon Bay waters also had different results where the highest abundance value of aquatic invertebrates was $5.59 \mathrm{ind} / \mathrm{m}^{2}$, and the lowest was $0.04 \mathrm{ind} / \mathrm{m}^{2}$. Causes of the high abundance of invasive aquatic invertebrates in Batee Dua Islet are thought to be caused by physical and chemical factors in the waters that support invasive aquatic invertebrates growth. According to [19], the high abundance of aquatic invertebrates in the research location is due to the suitability of their habitat for aquatic invertebrates. The low abundance of invasive aquatic invertebrates in Limau Island is thought to be related to the percentage of coral cover in that location. According to [18], the abundance of aquatic invertebrates at the study site was influenced by the coral cover percentage.

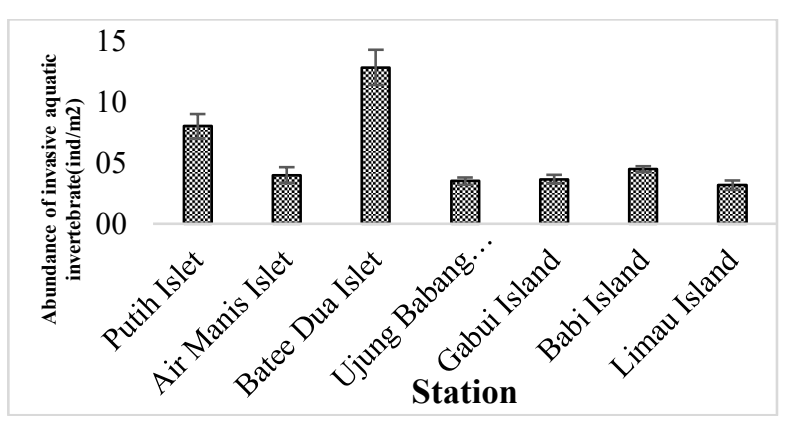

Fig. 3. The abundance of invasive aquatic invertebrates.

The difference in the abundance of invasive aquatic invertebrates at each station in the KKPD PISISI is thought caused by differences in the substrate from each station and other chemical and physical factors. It is supported by the opinion of [20], which statedthat differences in the abundance of aquatic invertebrates can be caused by the suitability of the habitats occupied by the organisms. High species abundance was found at Batee Dua Islet is Diadema antillarum as much as 6.17 
ind $/ \mathrm{m}^{2}$ and Acanthaster planci as much as $5.83 \mathrm{ind} / \mathrm{m}^{2}$. The high abundance of Diadema antillarum is thought to be caused by the substrate at the Batee Dua Islet location in the form of coral fragments and sand. According to [21], the substrate in the form of coral fragments, sand, and muddy sand is suitable for sea urchin life because coral fragments can grow algae. Sea urchins use seagrass and algae as food sources [22].

The high abundance of Acanthaster planci is caused by food availability in the Batee Dua Islet location, namely coral reefs, which are the types of coral that Acanthaster planci likes. [23] stated that certain coral species contributed to the high abundance of Acanthaster planci. According to [24], Acanthaster planci does not prey on all types of corals but generally chooses dominant coral colonies such as Acropora, Montipora, Seriatopora, and Pocillopora. Another factor that causes the high species of Diadema antillarum and Acanthaster planci is assumed due to the appropriate quality of the waters for these biota's growth. The brightness at Batee Dua Islet is relatively high, namely $5-10 \mathrm{~m}$, which causes sunlight to still penetrate to the bottom of the water. Therefore, photosynthesis still occurs in these waters. The deeper the waters, the less light can penetrate the bottom of the water. [25] stated that if the deeper the waters, the waters' productivity decreases, and the organic matter contained in the waters is small so that the density of organisms is low. Apart from that, the salinity and temperature at the Batee Dua Islet supports the growth of invasive aquatic invertebrates with a salinity of $32.7 \%$ and a temperature of $29.7 \mathrm{C}$. This is consistent with the statement of [26] that good salinity for the growth of marine biota is $25-40 \%$ and the normal temperature of water for marine life ranges from 20 $30^{\circ} \mathrm{C}$.

The low abundance of invasive aquatic invertebrates at Limau Island station is thought not to be influenced by water parameters. The brightness value of Limau Island waters reaches a depth of $10 \mathrm{~m}$, a salinity of 31.9 $\%$ and a temperature of $29.7^{\circ} \mathrm{C}$, which supports the growth of invasive aquatic invertebrates. The cause of the abundance of species at this station is related to the live coral cover at that location. A low abundance was found in the species Achantaster planci, Culcita novaeguineae, and Drupella sp. with a value of 0.17 $\mathrm{ind} / \mathrm{m}^{2}$ where these three species make live corals as food (Figure 4).



Fig. 4. The abundance of invasive aquatic invertebrates by species.
Live coral cover at Limau Island station (Figure 5) has a $41.67 \%$ value, which is categorized as moderate. Although the percentage of live coral cover is moderate, coral predators are thought to have the preferred coral species. [27] Drupella sp. does not prey on all types of coral but also selects the form of coral colony growth, the ease of taking live coral tissue, the production of mucus from the coral, the nutritional value of coral tissue as well as the ability of stinging cell defense from the coral. Based on the results of research conducted by [28] regarding the food preferences of Drupella sp. indicates that Drupella sp has a high degree of preference for certain coral species.

Achantaster planci also has a food preference for certain types of corals. Based on [29] research, this starfish has shown a preference for food in experiments conducted in the laboratory where Acropora corals are preferred over Fungia corals. Other research conducted by [30] regarding the predation rate of Achantaster planci showed that the coral's growth form also determines the food choices of this starfish species, where the tabulate growth form has a higher predation rate than the submassive growth form.

Sea star Culcita novaeguineae also shows a preference for the type of coral eaten. Based on research conducted by [31], observations made in the field showed that Culcita novaeguineae preferred Acropora and Monopora corals to Porites corals. Another thing that is thought to be low in Culcita novaeguineae abundance is water depth. According to [32] several individuals of Culcita novaeguineae were more frequently found at depths of $1 \mathrm{~m}-2 \mathrm{~m}$. Besides, [32] also stated that Culcita novaeguineae is the dominant type found in sandy seagrass microhabitates.

\subsection{Biological index of invasive aquatic invertebrates}

The biotic index of invasive aquatic invertebrates in the KKPD PISISI can be shown through the diversity index (H '), Evenness (E), and dominance (C). These three indices indicate whether a community has diversity or species domination. The diversity value $\left(\mathrm{H}^{\prime}\right)$ of invasive aquatic invertebrates in the KKPD PISISI can generally be classified into the moderate category with a value of 1.50 (Table 1). The $\mathrm{H}$ 'value of invasive aquatic invertebrates was highest at station Babi Island with a value of 1.89, and the lowest was at Air Manis Islet station with a value of 1.06 . Both of these values are still medium categories. Where according to [14], if the value of $H$ 'ranges from $1-3$, then the diversity is classified as moderate.

The diversity value $\left(\mathrm{H}^{\prime}\right)$ which belongs to the medium category at the research location is thought to be caused by the small number of invasive aquatic invertebrates that are found in the research location and have different abundances. According to [15], a community is said to have high species diversity if it is composed of many species with the same or nearly the same species abundance and a community has low species diversity if the community is composed of very few species and only a few dominant species. The higher 
the $\mathrm{H}$ 'value, the more variety of invasive aquatic invertebrates in these waters.

Table 1. The biological index of invasive aquatic invertebrates.

\begin{tabular}{|c|c|c|c|c|c|c|}
\hline Station & H' & Cat. & E & Cat. & C & Cat. \\
\hline Putih Islet & 1.32 & $\begin{array}{c}\text { Mod } \\
\text { erate }\end{array}$ & 0.95 & High & 0.49 & Low \\
\hline $\begin{array}{c}\text { Air Manis } \\
\text { Islet }\end{array}$ & 1.06 & $\begin{array}{c}\text { Mod } \\
\text { erate }\end{array}$ & 0.97 & High & 0.59 & $\begin{array}{c}\text { Mod } \\
\text { erate }\end{array}$ \\
\hline $\begin{array}{c}\text { Batee Dua } \\
\text { Islet }\end{array}$ & 1.33 & $\begin{array}{c}\text { Mod } \\
\text { erate }\end{array}$ & 0.96 & High & 0.44 & Low \\
\hline $\begin{array}{c}\text { Ujung } \\
\text { Babang } \\
\text { Islet }\end{array}$ & 1.71 & $\begin{array}{c}\text { Mod } \\
\text { erate }\end{array}$ & 1.23 & High & 0.36 & Low \\
\hline $\begin{array}{c}\text { Gabui } \\
\text { Island }\end{array}$ & 1.71 & $\begin{array}{c}\text { Mod } \\
\text { erate }\end{array}$ & 1.06 & High & 0.38 & Low \\
\hline $\begin{array}{c}\text { Babi } \\
\text { Island }\end{array}$ & 1.89 & $\begin{array}{c}\text { Mod } \\
\text { erate }\end{array}$ & 1.36 & High & 0.29 & Low \\
\hline $\begin{array}{c}\text { Limau } \\
\text { Island }\end{array}$ & 1.47 & $\begin{array}{l}\text { Mod } \\
\text { erate }\end{array}$ & 0.91 & High & 0.50 & Low \\
\hline Average & 1.50 & $\begin{array}{c}\text { Mod } \\
\text { erate }\end{array}$ & 1.06 & High & 0.44 & Low \\
\hline Note Cat. Is Category
\end{tabular}

Note. Cat. Is Category

The diversity value $\left(\mathrm{H}^{\prime}\right)$, which belongs to the medium category at the research location, is thought to be caused by the small number of invasive aquatic invertebrates found in the research location and have different abundances. According to [15], a community is said to have high species diversity if it comprises many species with the same or nearly the same species abundance. A community has low species diversity if the community comprises very few species and only a few dominant species. The higher the $H$ ' value, the more variety of invasive aquatic invertebrates in these waters.

The Evennes value (E) of invasive aquatic invertebrates in the KKPD PISISI can be categorized as high, namely 1.06 . The highest $\mathrm{E}$ value was found at Babi Island station, namely $1.36 \mathrm{ind} / \mathrm{m}^{2}$, and the lowest was found at Limau Island station with a value of 0.91 . Both values are classified as high uniformity, where according to [14], if the value of $E>0.6$, then the evenness is high and is classified as a stable community.

Evenness shows the stability of a community through high and low values of the evenness index. According to [33], if the uniformity index value approaches 1 , the community can be said to be stable. The high uniformity index value shows the even distribution of invasive aquatic invertebrates. As stated by [34], if the evenness is close to 1 , then the uniformity between species is classified as evenly distributed.

The dominance value (C) of invasive aquatic invertebrates in the KKPD PISISI is generally in the low category, with an average value of 0.44 . According to [14], if the $\mathrm{C}$ value ranges from $0.00-0.50$, it is in a low category. This indicates that there is no dominance of certain invasive aquatic invertebrates in the KKPD PISISI. According to [35], if the value of $\mathrm{C}$ is getting smaller, the dominance of species in an area will decrease. The low $\mathrm{C}$ value is thought to be due to the even distribution of species shown by the high $\mathrm{E}$ value of invasive aquatic invertebrates. A species dominance with other species occurs when the $\mathrm{C}$ value approaches 1 [14].

\subsection{Distribution of invasive aquatic invertebrates}

The distribution shows the distribution pattern of an organism in a community. Each species has a unique distribution according to the type of habitat. Distribution occurs due to differences in response to habitat [36]. The distribution of invasive aquatic invertebrates in the KKPD PISISI is generally classified as a group, except for Culcita novaeguinaea, which has a uniform distribution (Table 2).

The distribution of invasive aquatic invertebrates in the KKPD PISISI is generally classified as a cluster, except for Culcita novaeguinaea, which has a uniform distribution. Similar distribution occurs due to antagonistic interactions between individuals due to competition for resources. According [14], similar distribution can occur if the competition among individuals is robust, which encourages space division.

The clustered distribution occurs due to the high availability of organic matter in the waters [38]. Flow has a relationship in the availability of organic matter in waters. According to Muqsit et al. (2016), currents play a role in the movement of nutrients, larvae, sediment, and oxygen. The current speed supports this in the KKPD PISISI, ranging from $0.07 \mathrm{~m} / \mathrm{s}-0.19 \mathrm{~m} / \mathrm{s}$. The clustered distribution of invasive aquatic invertebrates in the KKPD PISISI is thought to be related to the substrate shape. In general, the substrate form in the KKPD PISISI consists of sandy substrate and coral fragments. Based on the research conducted by [39], cluster distribution is related to the shape of the substrate in the form of chunks of coral, coral rubble, and a little sand and coral area reef flats. According to [36] the most common distribution is group distribution because individuals in the population tend to form groups of various sizes.

Table 2. The distribution of invasive aquatic invertebrates.

\begin{tabular}{|c|c|c|c|}
\hline No & Species & Distribution & Category \\
\hline 1. & Acanthaster planci & 1.67 & Clustered \\
\hline 2. & Culcita novaeguinaea & 0.62 & Uniform \\
\hline 3. & Diadema antillarum & 1.22 & Clustered \\
\hline 4. & $\begin{array}{l}\text { Spirobranchus } \\
\text { giganteus }\end{array}$ & 1.66 & Clustered \\
\hline 5. & Drupella sp. & 1.88 & Clustered \\
\hline
\end{tabular}

\subsection{Comparison of Abundance of Invasive Aquatic Invertebrates to the Percentage of Coral Reef Cover}

The abundance of invasive aquatic invertebrates and the percentage of coral reef cover have different values at each KKPD PISISI station. The results showed a difference between the abundance of invasive aquatic invertebrates and the percentage of coral cover where 
the low coral cover had a high abundance of invasive aquatic invertebrates, namely at station Batee Dua Islet. In contrast, high coral cover has an abundance of less invasive aquatic invertebrates at the Gabui Island station (Figure 5).

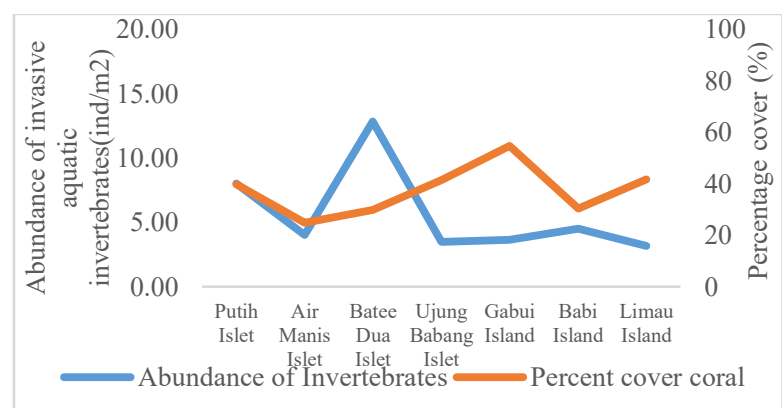

Fig. 5. The abundance of invasive aquatic invertebrates with live coral cover.

The high and low abundance of invasive aquatic invertebrates is thought to be related to the coral cover percentage. A study conducted by [40] high percentage of coral cover is associated with a low abundance of invasive aquatic invertebrates, so that predation of coral reefs is not too high. Another statement is supported by [41], which stated that invertebrate predation activities would increase if there were a decrease in coral cover. Another study conducted by [42] showed that a decrease in the percentage of live coral cover has high invasive aquatic invertebrates.

Other causes that affect the abundance of invasive aquatic invertebrates are thought to be caused by human activities such as fishing activities. The KKPD PISISI area is an area used by fishermen to catch fish and other marine biotas, so there is a possibility that the high and low abundance of invasive aquatic invertebrates can be caused by fishing. This is consistent with [43] which states that intensive fishing activities on coral reefs can impact ecosystems because they can change the composition of organisms in the ecosystem and change the processes that occur in coral reef ecosystems.

\section{Conclusion}

The community structure of the invasive aquatic invertebrates in the KKPD PISISI is in a suitable category, as indicated by the total abundance of invasive aquatic invertebrates of $39.67 \mathrm{ind} / \mathrm{m}^{2}$. The diversity index of invasive aquatic invertebrates of 1.50 with moderate category, index evenness of 1.06 with a high category, and dominance index of 0.44 with a low category. Distribution of invasive aquatic invertebrates in the KKPD PISISI is classified into clustered distribution. The value of the highest abundance of invasive aquatic invertebrates was $12.83 \mathrm{ind} / \mathrm{m}^{2}$, and the percentage of coral cover was $29.83 \%$. The lowest abundance of invasive aquatic invertebrates was 3.67 ind $/ \mathrm{m}^{2}$. The percentage of coral cover was $54.67 \%$, indicating an influence between the abundance of aquatic invertebrates invasive to the coral cover percentage.
Acknowledgement. The authors would like to thank Fauna and Flora International (FFI) Aceh for facilitating this research activity and Ocean Diving Club (ODC) team and ODC who have helped during the research

\section{References}

1. S. Hasma, B. Sadarun, R.D. Palupi, Sapa Laut 4, 2 (2019)

2. P.W. Glynn, I.C. Enochs, Invertebrates and their roles in coral reef ecosystems. In Coral reefs: an ecosystem in transition 273- 325 (2011)

3. J.E. Havel, K.E. Kovalenko, S.M. Thomaz, S. Amalfitano, L.B. Kats, Hydrobiologia 750 (2015)

4. İ. E. Büyüktahtakın, Z. Feng, G. Frisvold, F. Szidarovszky, App. Math 4 (2013)

5. D.W. Schindler, B.R. Parker, Wat. Ai. So. Poll. Foc 2 (2002)

6. R.D. Rotjan, S. M. Lewis. Mar. Eco. Prog. Ser. 367 (2008)

7. N.A. Bax, Williamsons, M. Aguero, E. Gonzalez, W. Geeves. Mar. Poli 27 (2003)

8. L.M. Herborg, P. O'Hara, T.W. Therriault, J. of App. Ecol 46 (2009)

9. M.Y. Sastri, Percentage of cover and distribution of benthic invasion of invertebrates in coral reef ecosystems (Thesis, Bogor Agricultural University, 2016)

10. R.T. Utami. Relationship of coral reef ecosystem conditions to the distribution of coral killer invertebrates in the waters of Pulau Dua and Pulau Tikus, Bengkulu as well as the Island of the Netherlands and Pulau Dapur, Kepulauan Seribu, Jakarta (Thesis, Bogor Agricultural University, 2019)

11. S. Nasution. Research Methods: Scientific Research (Bumi Aksara, Jakarta, 2004)

12. L. Collin, A.C. Arneson, Tropical pacific invertebrates (Coral Reef Press, California, 1995)

13. T. Rahmasari, T. Purnomo, R. Ambarawati, Biosaintifika, 7, 1 (2015)

14. E.P. Odum, Basic Ecology (Saunders College Publishing, 1983)

15. A. Soegianto, Quantitative ecology (Indonesian National Business, 1994)

16. S. English, C. Wilkinson, V. Baker, Survey manual for tropical marine resources 2 nd edd, Townsville: Australian Institute of Marine Science (1997)

17. Keputusan Menteri Lingkungan Hidup Nomor 04/ 02/2001 (2001)

18. S. Bangapadang, E. Emiyarti, W. Nurgayah, Sapa Laut 4, 2 (2019)

19. H.A.W. Cappenberg, Ocea. Limnno 37, 2 (2011)

20. D. Alwi, S.H. Muhammad, S. Bisi, J. Archip. Mar. Sci 1, 1(2018)

21. N.P.E. Noviana, P.G.S. Julyantoro, D.A.A. Priestess, Curr. Trends in Aquat Sci II, 1 (2019) 
22. S. Suryanti, W. Wahyuni, J. Fish. Sci 10, 1 (2014)

23. S. Alustco, Y. Wardiatno, I. Setyobudiandi, JIAFS 17, 1 (2011)

24. N. P. Zamani, Oseana 18, 2 (2015)

25. J. Souhoka, S. Patty, Scien. Jour 1, 3 (2013)

26. G. Gabbi. Shells: guide to the jewels of the sea, Periplus, Turin (1999)

27. B. Morton, G. Blackmore, C.T. Kwok, JMS 68, 3 (2002)

28. A. Aziz, Oseana XXI, 3 (1996)

29. C. Rani, S. Yusuf, F. D. S. Benedikta, J. Fac. Mar. Fish. Sci. (2007)

30. J. Bell, 2008. Feeding preferences of the cushion star Culcita novaeguineae in the presence of the crown of thorns starfish Acanthaster planci. UCB Moorea Class: Biology and Geomorphology of Tropical Islands, Student Research Paper (2008)

31. D.A. Setyowati, Supriharyono, W.T. Taufani, J. Maquares 6, 4 (2017)

32. I. Irawan. Structure of mollusc communities (gastropods and bivalves) and their distribution in Pulau Burung and Pulau Tikus, Pari Island Cluster, Kepulauan Seribu (IPB University, 2008)

33. A.M. Pirzan, Utojo, M. Atmomarso, M. Tjaronge, A.M. Tangko, and Hasnawi, Indones. Fish. Res J11, 5 (2005)

34. A. Indarjo, H. Retno, I. Samidjan, S. Anwar, J. Mar. Sci. (2007)

35. R. Werdiningsih. Crab Community Structure in Mangrove Habitat, Tanjung Pasir Beach, (Tanggerang, Banten, IPB University, 2005)

36. M.C. Molles, Ecology: concepts and applications (5th ed.) (NY: McGraw-Hill, 2010)

37. N. Yuniarti. 2012. Diversity and Distribution of Bivalves and Gastropods (Mollusks) in the Glayem Juntinyuat Coast of Indramayu, West Java (IPB University, 2012)

38. S. Steven, S. Nasution, Thamrin, SOJ 1, 2 (2014)

39. R. Riska, B. Sadarun, L.O.M.Y. Haya, JMLI 2, 6 (2013)

40. L. Lalang, B. Sadarun, L.O.M.Y. Haya, JMLI 1, 1 (2013)

41. R. Mauliza, D.J. Prihadi, M.L. Syamsuddin, JMF 7, 2 (2016)

42. C. Rani, Rev. Bionatura 5, 2 (2003) 